\title{
A MEDIAÇÃo PENAL EM PORTUGAL E A VISÃO DOS MEMBROS DO MINISTÉRIO PÚBLICO CRIMINAL: BREVES E (DES)PRETENSIOSAS CONSIDERAÇÕES ${ }^{1}$
}

\section{CRIMINAL MEDIATION IN PORTUGAL AND THE VIEW OF THE CRIMINAL PROSECUTORS: BRIEF AND (UN)PRETENTIOUS CONSIDERATIONS}

Fernando Laércio Alves da Silva

Professor Adjunto III - Universidade Federal de Viçosa. PósDoutorando - Centro de Estudos Sociais da Universidade de Coimbra, Portugal. Doutor em Direito Processual - Pontifícia Universidade Católica de Minas Gerais. Mestre em Direito Faculdade de Direito de Campos/RJ. Bacharel em Direito Universidade Federal de Viçosa/MG. Advogado. Pesquisador integrante do Grupo de Pesquisa em Direito, Política, Economia e Sociedade. Viçosa/MG. E-mail: fernando.laercio@ufv.br

RESUMO: A mediação como técnica alternativa de resolução de conflitos penais ancorada na ideia de justiça restaurativa foi introduzida em Portugal pela Lei n. 21/2007. Após um começo promissor, aos poucos a mediação foi sendo abandonada, estando em estado letárgico desde 2017. Buscando compreender as possíveis causas dessa decadência e perspectivar a possibilidade de sua retomada, analisamos neste trabalho se a visão e atuação dos membros do Ministério Público Português em relação à mediação figura entre as causas de seu abandono. Verificação essa conduzida, metodologicamente, por meio da coleta de dados documentais e pela auscultação dos próprios membros do Ministério Público.

PALAVRAS-CHAVE: Sistema de justiça penal; mediação penal; justiça restaurativa; ministério público; Portugal.

\footnotetext{
${ }^{1}$ Artigo recebido em 27/07/2020 e aprovado em 01/11/2020.
} 
ABSTRACT: Mediation as an alternative technique for solving criminal conflicts anchored in the idea of restorative justice was introduced in Portugal through Law no. 21/2007. After a promising start, mediation was gradually abandoned, having been in a lethargic state since 2017. Seeking to understand the possible causes of this decay and to envisage the possibility of its resumption, we analysed in this paper whether the view and the actuation of members of the Portuguese Prosecutor's Office in relation to mediation among the causes of its abandonment. This verification was carried out, methodologically, through the collection of documentary data and by listening to the members of the Prosecutor's Office themselves.

KEY WORDS: Criminal justice system. Criminal mediation. Restorative justice. Criminal prosecutor. Portugal.

\section{Considerações introdutórias}

Desde a entronização formal do instituto da mediação penal em Portugal por meio da promulgação da Lei n. 21/2007, os caminhos trilhados para sua efetiva implantação, assim considerados tanto as medidas burocráticas estabelecidas pelo Estado Português para estruturação dos órgãos responsáveis pela realização da mediação penal, como também os mecanismos de formação e capacitação dos agentes públicos responsáveis por ela tornaram-se objetos de um número considerável de investigações.

De um lado isso se explica pela própria natureza inovadora da mediação penal que, embora já bem desenvolvida e estruturada em outros Estados, ainda era pouco conhecida no plano acadêmico e totalmente desconhecida no plano prático-processual. Por si só, portanto, capaz de despertar a curiosidade acadêmica sobre como a proposta. Não bastasse isso, o contexto no qual se gestou a mediação penal para Portugal, decorrente muito mais de uma exigência do Conselho de Ministros da União Europeia ${ }^{2}$ do que uma iniciativa gestada internamente torna necessário o acompanhamento de seus desdobramentos a fim

\footnotetext{
${ }^{2}$ Falamos aqui especificamente da Decisão-Quadro n. 2001/200/JAI, de 15 de março de 2001 (CARMO, Rui do. Um exercício de leitura do regime jurídico da mediação penal. Revista Portuguesa de Ciência Criminal, Coimbra, ano 20, n. 3, jul-set. 2010, p. 452-453; LHUILLIER, Julien. The quality of penal mediation in Europe. In: Working Group on Mediation of European Commission for the Efficiency of Justice. Strasbourg: Concil of Europe, 22. ago.2007).
} 
de se verificar o grau de aderência alcançado pela inovação legislativa no cotidiano processual penal lusitano. Por um terceiro lado, tendo em conta que esse novel modelo de solução de conflitos penais impacta - ou pelo menos deve impactar - na forma como os sujeitos processuais enxergam o sistema penal e dentro dele conduzem suas atividades, com especial atenção ao grupo dos sujeitos processuais vinculados ao Ministério Público, considerados peças-chave para o bom sucesso da proposta, explica-se o interesse investigativo-científico em torno da mediação penal com fincas a verificar como o instituto impactou no modo de atuar dos membros do Ministério Público em Portugal e vice-versa, isto é, como a adesão (ou não) desses agentes estatais impactou no sucesso/insucesso da proposta.

É exatamente sob esse terceiro eixo de interesse investigativo que se desenvolveu a pesquisa que resulta no presente artigo, sendo nosso objetivo geral identificar o grau de compromisso dos membros do Ministério Público de Portugal com a implementação da mediação penal enquanto medida de solução alternativa de litígios e seu impacto no sucesso/insucesso da medida doze anos depois da promulgação da Lei n. 21/2007 que a instituiu no país. E como objetivos específicos buscamos identificar o perfil dos membros do Ministério Público de Portugal que atuam na seara criminal, seu nível de formação em relação aos fundamentos da mediação e de experiência concreta com o instituto, sua compreensão acerca dos fundamentos do processo penal português e o grau de compatibilidade entre eles e o mecanismo da mediação penal e, por fim, proceder o confronto entre esses elementos e os resultados alcançados ao longo dos doze anos de desenvolvimento da mediação penal em Portugal.

Para tanto, metodologicamente a investigação se conduziu sobre dois pilares:

O caminho bibliográfico-documental, consistente no levantamento, de um lado, dos dados oficiais da mediação penal em Portugal desde a edição da Lei n. 21/2007, dados esses obtidos tanto por meio da consulta aos relatórios consolidados anualmente expedidos pela Direção-Geral da Política de Justiça de Portugal (DGPJ), chamados Estatísticas da Justiça ${ }^{3}$, como também por meio de solicitação direta ao referido órgão em relação aos

\footnotetext{
${ }^{3}$ Disponíveis no sítio eletrônico <https://estatisticas.justica.gov.pt/sites/siej/pt-pt>.
} 
dados não disponibilizados nos referidos relatórios estatísticos ${ }^{4}$ e, em relação a dados mais antigos que não foram encontrados nos arquivos daquele órgão, por meio da consulta a trabalhos outros que anteriormente se debruçaram sobre a temática da mediação penal em Portugal $^{5}$ e ainda por meio de consulta ao Quadro Estatístico de Magistrados 2019, elaborado pelo Conselho Superior do Ministério Público de Portugal ${ }^{6}$. E, lado outro, consistente também no levantamento dos resultados de trabalhos científicos anteriormente desenvolvidos nos campos do Direito, das Ciências Sociais e da Sociologia tendo por objetos de análise tanto o desenvolvimento da mediação penal em si como também a atuação do Ministério Público em relação a tal instituto especificamente e, de modo mais geral, na seara criminal, sempre tomando por limite espacial o Estado Português.

Para tanto, tomamos como corte temporal para a coleta de dados o intervalo compreendido entre os anos de 2000 e 2019, permitindo-nos verificar não apenas o cenário de discussão da mediação penal $^{7}$, como do próprio contexto de transformação do modelo de atuação do Ministério Público na seara criminal, uma vez que dentro desse mesmo intervalo temporal foram implementadas diversas reformas no sistema de justiça penal português para além da introdução da mediação penal como método alternativo de resolução de litígios.

Além disso, procedeu-se, ainda no que diz respeito ao aspecto bibliográficodocumental da pesquisa, à busca de artigos acadêmico-científicos que tivessem por objeto as temáticas da mediação penal e do Ministério Público no contexto das reformas implementadas no sistema de justiça penal português. Ambas as buscas foram realizadas nas plataformas eletrônicas B.On, Jstore e Scielo e a base de dados de obras físicas do Portal das Bibliotecas da Universidade de Coimbra ${ }^{8}$.

\footnotetext{
${ }^{4} \mathrm{O}$ inteiro teor tanto das correspondências eletrônicas trocadas entre o autor e o setor responsável da DGPJ encontram-se em posse daquele e assim permanecerão pelo intervalo temporal de cinco anos, contados do encerramento da investigação que resultou no presente texto.

${ }^{5}$ Nesse sentido, temos o pensamento de Cristina Rego de Oliveira (Sobre o que a mediação penal (não) pode ser: uma abordagem crítica das práticas luso-brasileiras. Revista Jurídica do Ministério Público do Estado do Paraná, Curitiba, a. 2, n. 3, p. 51-97.) e de Cláudia Cruz Santos (A justiça restaurativa - Um modelo de reacção ao crime diferente da Justiça Penal. Por quê, para quê e como? Coimbra: Coimbra Editora, 2014).

${ }^{6} \mathrm{O}$ documento encontra-se em <http://www.ministeriopublico.pt/sites/default/files/documentos/pdf/quadroestatistico-magistrados-2019.pdf $>$.

${ }^{7}$ O que se fez segundo os passos de Fernando Laercio Alves da Silva e Luca Verzelloni (A mediação penal em Portugal doze anos depois: início, meio e fim(?). Revista de Informação Legislativa. Brasília, n. 227, jul-ago. 2020. No prelo).

${ }^{8} \mathrm{http}: / /$ webopac.sib.uc.pt/search*por $\sim \mathrm{S} 30$
} 
Para a primeira temática (da mediação penal em Portugal), a busca fora realizada entre os dias 01 e 19 de dezembro de 2019, utilizando-se como critérios de busca as expressões mediação penal, Portugal e Sistema Penal. As bases de dados Scielo e JStore não reportaram nenhum resultado, enquanto a base de dados da B.On reportou cinco resultados e o Portal das Bibliotecas da Universidade de Coimbra reportou dezesseis resultados. Para a segunda temática (do Ministério Público no contexto das reformas implementadas no sistema de justiça penal), a busca foi realizada entre os dias 10 e 17 de maio de 2020, utilizando-se como critérios de busca as expressões Ministério Público, Portugal e reformas do sistema de justiça penal. Em relação a ela, as bases de dados Scielo, JStore e B.On não reportaram resultados, enquanto o Portal das Bibliotecas da Universidade de Coimbra reportou sete resultados.

O segundo caminho metodológico trilhado, tratando-se de investigação de viés etnográfico, consistiu na coleta de informações diretamente dos agentes públicos que são o objeto de análise, os membros do Ministério Público de Portugal. O que se materializou por meio da aplicação de um questionário estruturado ${ }^{9,10}$, elaborado e encaminhado por meio da Plataforma Google Forms e respondido eletronicamente por dezesseis indivíduos integrantes da carreira do Ministério Público de Portugal com atuação na área criminal ${ }^{11}$.

Neste ponto necessário esclarecer que não houve estabelecimento de contato direto entre este investigador e os inquiridos. Tanto por conta das diretrizes internas do Ministério Público de Portugal como também para preservação do sigilo de identidade dos inquiridos, todo o diálogo preparatório à aplicação do questionário foi travado com a Procuradoria Geral da República de Portugal, órgão superior do Ministério Público, a qual se encarregou de divulgar o link de acesso ao questionário em seus sistemas eletrônicos internos, de modo a leva-lo ao conhecimento de seus membros. Consequentemente, os dezesseis indivíduos integrantes da carreira do Ministério Público de Portugal que responderam o questionário componente da pesquisa o fizeram espontaneamente.

\footnotetext{
${ }^{9}$ Conforme Cristiano Lessa de Oliveira (Um apanhado teórico-conceitual sobre a pesquisa qualitativa: tipos, técnicas e características. Revista Travessias, Cascavel, v. 2, n. 3, 2008, p. 12).

${ }^{10} \mathrm{O}$ questionário, tanto em sua versão eletrônica como em sua versão impressa, encontra-se arquivado pelo por este investigador e também, mas apenas em sua versão impressa, junto à Instituição na qual se desenvolveu a pesquisa.

${ }^{11}$ Foram inquiridos membros do Ministério Público atualmente lotados nas Comarcas de Açores, Aveiro, Braga, Bragança, Coimbra, Faro, Lisboa, Porto, Santa Maria da Feira, Santarém, Vila Nova de Gaia e no Gabinete da Procuradoria Geral da República.
} 
Compilados e comparados os dados levantados na fase investigativa bibliográficodocumental e na fase investigativa de campo, realizada por meio da aplicação de questionário aos membros do Ministério Público, passamos à tarefa de interpretá-los. E é exatamente o resultado dessa tarefa interpretativa que se apresenta ao longo do presente texto.

Finalmente, necessário se faz esclarecer que a leitura e interpretação dos dados coletados se deram a partir - e nos limites - dos marcos teóricos da teoria estruturalista do processo $^{12}$ e, a partir dela, também do modelo constitucional de processo ${ }^{13}$, dos conceitos de justiça restaurativa ${ }^{14}$ e, por fim, da perspectiva cappellettiana de acesso à justiça ${ }^{15}$, a partir da qual vislumbramos o papel do Ministério Público na seara criminal na atual quadra histórica $^{16}$. Bases teóricas essas essenciais para a boa compreensão tanto do papel do Ministério Público nas estruturas processuais definidas para Portugal no Século XXI, como também do comportamento e da compreensão de seus membros acerca desse papel e como elas impactaram no grau de desenvolvimento da mediação penal alcançado após pouco mais de uma década da aprovação da Lei n. 21/2007.

\section{A mediação penal em Portugal: de onde veio e para onde (ou até onde) foi?}

Formalmente, o instituto da mediação penal em Portugal tem seu nascedouro em 12 de junho de 2007, quando o Projeto de Lei n. 107-X, de 2006, aprovado em 04 de abril de

\footnotetext{
${ }^{12}$ Por todos, Elio Fazzallari (Istituzioni di diritto processuale. 8. Ed. Milani: Padova, 1996) e Flaviane de Magalhães Barros (O processo, a jurisdição e a ação sob a ótica de Elio Fazzalari. Revista Eletrônica da Faculdade Mineira de Direito, Belo Horizonte, v. 1, ano 2, p. 01-29, 2003).

${ }^{13}$ Por todos, Fernando Laércio Alves da Silva (Processo Constitucional: o processo como locus devido para o exercício da democracia. Revista Eletrônica de Direito Processual, Rio de Janeiro, v. 16, n. 16, p. 157-188, jul-dez.2015; Da neoinquisitoriedade à democracia: bases para o estabelecimento de um novo standard comportamental para os sujeitos no processo penal brasileiro. 2017390 f. Tese (Doutorado) - Pontifícia Universidade Católica de Minas Gerais, Programa de Pós-Graduação em Direito.

${ }^{14}$ LHUILLIER, Julien. The quality of penal mediation in Europe. In: Working Group on Mediation of European Commission for the Efficiency of Justice. Strasbourg: Concil of Europe, 22. ago.2007; SANTOS, Cláudia Cruz. A justiça restaurativa - Um modelo de reacção ao crime diferente da Justiça Penal. Por quê, para quê e como? Coimbra: Coimbra Editora, 2014; CAMPANÁRIO, Micaela Susana Nóbrega de Abreu. Mediação Penal. Cívitas, Porto Alegre, v. 13, n.1, p. 118-135, jan-abr.2013.

${ }^{15}$ CAPPELLETTI, Mauro; GARTH, Bryant. Acesso à Justiça. Tradução de Ellen Gracie Northfleet. Porto Alegre: Sergio Antônio Fabris, 1988.

${ }^{16}$ DIAS, João Paulo. O ministério público no acesso ao direito e à justiça: "porta de entrada" para a cidadania. Coimbra: Almedina/Centro de Estudos Sociais da Universidade de Coimbra, 2013; DIAS, João Paulo. Desafios ao Ministério Público em Portugal: porta de entrada para a cidadania. Revista de Sociologia Configurações, Coimbra, n. 13, p. 27-46, 2014.
} 
2007 pela Assembleia da República de Portugal, finalmente restou sancionado, convertendo-se na Lei n. 21/2007. E, de fato, por estarmos falando de um instituto jurídico aplicável ao direito penal e ao direito processual penal, nos quais o princípio da estrita legalidade tem posição basilar e inafastável, toda e qualquer análise realizada acerca da mediação penal enquanto instituto jurídico concreto ou em ação somente pode ser por corte temporal inicial o momento de sua introdução no ordenamento jurídico legal.

O que não quer dizer que os eventos anteriores a seu nascimento devam ser esquecidos. Mesmo porque toda a complexidade de um dado instituto jurídico somente é acessível se nos dedicamos a estudá-lo e compreendê-lo desde suas bases estruturais, ainda no campo teórico e pré-legislativo. A não ser, é claro, que se esteja a ler o ordenamento legal com inocência tal a ponto de se considerar o ato de promulgação de um texto legal como seu marco zero e absolutamente dissociado do arcabouço teórico que não apenas fomentou todo o debate legislativo, como também dá sustentação à adequada compreensão e interpretação do instituto, o que somente ocorreria se norteado por uma bolorenta ideia de que a norma legal seria um fim em si mesma, própria de um positivismo requentado. $\mathrm{O}$ que, de fato, não é o presente caso.

E isso torna necessário, ainda que em linhas gerais, retornarmos às origens do instituto da mediação penal em Portugal, o que, de um lado, nos conduz a algumas décadas pretéritas. Inicialmente à década de 80 do século $\mathrm{XX}$, quando a preocupação com a vítima do crime passou a ser objeto de discussão da Organização das Nações Unidas e do próprio Conselho Europeu ${ }^{17}$. Preocupação essa essencial à compreensão da justiça restaurativa, na qual se insere o instituto da mediação penal. E nos conduz também ao final da década de 90 do mesmo século e ao primeiro ano do corrente século XXI. Isso porque no ano de 1999, o Conselho de Ministros da União Europeia expediu a Recomendação R(99)19, de 15 de setembro, por meio da qual se orientava os Estados-membros à busca de métodos alternativos de solução dos conflitos de natureza penal, com especial olhar para a mediação

17 “O movimento favorável à mediação penal e a preocupação com a vítima encontram eco em vários diplomas internacionais, desde a Resolução 40/34 das Nações Unidas, de 1985, até as Recomendações R(85)11 e R(87)21 do Conselho da Europa (que abordam problemas como o da vitimização secundária), sem esquecer a Convenção Europeia Relativa à Indemnização (sic) de Vítimas de Infracções (sic) Violentas, aberta à assinatura dos estados membros do Conselho da Europa em Estrasburgo, em 24 de Novembro de 1983 (e que Portugal ratificou em 06 de março de 2000)." (ALMEIDA, Carlota Pizarro de. A propósito da decisão-quadro do Conselho de 15 de Março de 2001: algumas considerações (e interrogações) sobre a mediação penal. Revista Portuguesa de Ciência Criminal, Coimbra, ano 15, n. 3, jul-set.2005, p. 392). 
penal. E em 15 de março de 2001, no âmbito da mesma União Europeia, emitiu-se a Decisão-Quadro n. 2001/200/JAI, que de modo mais incisivo não apenas recomendou, mas determinou aos Estados-membros a instituição da mediação penal, estabelecendo como prazo final para tal a data de 22 de março de $2006^{18}$.

Percurso esse trilhado para compreendermos que a mediação penal - assim como a própria ideia de justiça restaurativa em si - não nasceu espontaneamente no seio da comunidade portuguesa, mas é ali inserido por conta de pressões e diretrizes de fora para dentro $^{19}$. Tanto que, como bem explica Carlota Pizarro de Almeida, diverso do que se verificou em outros Estados da União Europeia, Portugal, para dar cumprimento à Decisão-Quadro n. 2001/200/JAI, precisou criar um sistema do zero, já que, diverso do que havia em seu sistema de justiça civil, no qual já presentes estavam métodos alternativos de justiça junto aos juízes de paz, no campo do sistema penal não havia nada que lhe fosse semelhante $\mathrm{e}^{20,21,22}$.

${ }^{18}$ SANTOS, Cláudia Cruz. A justiça restaurativa - Um modelo de reacção ao crime diferente da Justiça Penal. Por quê, para quê e como? Coimbra: Coimbra Editora, 2014; CARMO, Rui do. Um exercício de leitura do regime jurídico da mediação penal. Revista Portuguesa de Ciência Criminal, Coimbra, ano 20, n. 3, p. 451-476, jul-set. 2010; SILVA, Fernando Laércio Alves da; VERZELLONI, Luca. A mediação penal em Portugal doze anos depois: início, meio e fim(?). Revista de Informação Legislativa. Brasília, n. 227, jul-ago. 2020. No prelo; ALMEIDA, Carlota Pizarro de. A propósito da decisão-quadro do Conselho de 15 de Março de 2001: algumas considerações (e interrogações) sobre a mediação penal. Revista Portuguesa de Ciência Criminal, Coimbra, ano 15, n. 3, p. 391-414, jul-set.2005.

${ }^{19}$ Nesse sentido, Micaela Susana Nóbrega de Abreu Campanário explica que "Surge da necessidade de dar cumprimento a algumas directrizes europeias de forma a integrar-se nesta "rede" internacional promotora de uma justiça de proximidade, assim como de integrar este paradigma de uma "nova" justiça restaurativa que tem vindo a afirmar-se também em todo o mundo, como complementar, se não mesmo, alternativa à justiça tradicional" (Mediação Penal. Cívitas, Porto Alegre, v. 13, n.1, jan-abr.2013, p. 120).

${ }^{20}$ Disse a autora à época que "Portugal, ao contrário do que sucede com alguns outros estados da União Europeia, não tem ainda a funcionar qualquer sistema de mediação penal, pelo que, para dar cumprimento à referida Decisão-Quadro, terá de criar um sistema ex novo." (ALMEIDA, Carlota Pizarro de. A propósito da decisão-quadro do Conselho de 15 de Março de 2001: algumas considerações (e interrogações) sobre a mediação penal. Revista Portuguesa de Ciência Criminal, Coimbra, ano 15, n. 3, jul-set.2005, p. 391).

${ }^{21}$ Cláudia Cruz Santos faz menção à existência de práticas restaurativas também na Lei Tutelar Educativa (Lei n. 106, de 14 de setembro de 1999), destinada ao tratamento dos adolescentes em conflito com a lei penal ou, nas palavras dela, da "delinquência juvenil" (SANTOS, Cláudia Cruz. A justiça restaurativa - Um modelo de reacção ao crime diferente da Justiça Penal. Por quê, para quê e como? Coimbra: Coimbra Editora, 2014, p. 613). Contudo, por entendermos, tal como ela, que os fundamentos do ordenamento protetivo das crianças e adolescentes sejam distintos em relação ao ordenamento regente do sistema penal (SILVA, Fernando Laércio Alves da; COLLI, Luciene Rinaldi. Breves análises sobre a proposta de redução da idade penal. Revista de Direito (Viçosa). Viçosa, v. 1, n. 2, 2004, p. 37-56), colocamos os mecanismos restaurativos previstos naquele diploma normativo ao lado dos mecanismos estabelecidos para o sistema civil português. E, com isso, mantemos a afirmação de que o sistema de justiça penal português desconhecia em seu plano normativo, até 2007, o modelo de medição penal ou mesmo qualquer outra proposta de solução alternativa de litígio ancorada nos fundamentos da justiça restaurativa.

${ }^{22}$ Novamente o pensamento de Cláudia Cruz Santos nos traz esclarecimentos relevantes: "Ao contrário do que tem sucedido em outros ordenamentos jurídicos que têm vindo a admitir a implementação de programas 
É fato que iniciativas outras ancoradas na ideia de consensualidade já existiam no direito processual penal português à altura da edição da Lei n. 21/2007, a dizer as práticas destinadas à suspensão provisória do processo penal nos casos autorizados em lei. Jamais se pode, porém, tentar estabelecer qualquer semelhança entre essas medidas e aquela que é objeto da Lei n. 21/2007. Longe disso, seguindo as lições de Cláudia Cruz Santos, o mais acertado é concluir que "a partir de uma ponderação do regime da suspensão provisória do processo e do processo sumaríssimo, o que se começa por enfatizar é que o consenso de que aqui se trata não é o mesmo consenso que constitui trave-mestra das práticas restaurativas $[\ldots]^{\prime \prime 23}$.

Embora se possa enxergar algum aspecto de consenso na suspensão provisória do processo, esse aspecto é sobremaneira limitado pela própria natureza do instituto, podendose falar mais em aceitação ou submissão do acusado à proposta de solução construída e apresentada unilateralmente pelo membro do Ministério Público e chancelada pelo juiz. Lado outro, quando nos voltamos para a mediação enquanto instituto ancorado na perspectiva da justiça restaurativa, devemos compreendê-la como uma "[...] espécie de 'autocomposição assistida' dos conflitos, na medida em que é da vontade das partes que decorre a celebração do acordo e são elas quem dirige as negociações e auxílio do mediador $[\ldots]^{\prime 24}$.

É muito mais, portanto, que um simples aceitar ou não, submeter-se ou não, anuir ou não a uma dada proposta de acordo, estando sua essência muito próxima, inclusive, na concepção fazzalariana de processo enquanto estrutura voltada à construção de um ato decisório. Não que o consenso entre as partes esteja na essência do conceito de Processo para Elio Fazzalari, mas sim o fato de que o consenso como elemento estruturante da

restaurativos mesmo não suportados por previsão legal expressa, em Portugal optou-se por criar um regime legal da mediação penal de adultos enquanto mecanismo de diversão, entre nós introduzida pela Lei $\mathrm{n}^{\circ}$ 21/2007, de 12 de Junho. Ora, o que merece ser sublinhado mesmo antes de se aprofundar a reflexão crítica sobre este regime jurídico é o aplauso que merece a previsão, em letra de lei, nomeadamente dos objectivos, dos critérios de envio para mediação, do procedimento a seguir, dos mecanismos de controlo. Ou seja: independentemente de tais opções merecerem (e, como se verá, nem sempre merecerão) um juízo de concordância, parece adequada a existência de uma sua disciplina legal.” (A justiça restaurativa - Um modelo de reacção ao crime diferente da Justiça Penal. Por quê, para quê e como? Coimbra: Coimbra Editora, 2014, p. 617).

${ }^{23}$ SANTOS, Cláudia Cruz. O direito processual penal português em mudança: rupturas e continuidades. Coimbra: Almedina, 2020, p. 217.

24 FRADE, Catarina. A resolução alternativa de litígios e o acesso à justiça: a mediação do sobreendividamento. Revista Crítica de Ciências Sociais, Coimbra, n. 65, mai.2003, p. 116. 
mediação penal deve ser compreendido sob as mesmas lentes utilizadas pelo autor italiano: as lentes da dialeticidade.

De modo tal que, como o processo deve ser compreendido como uma estrutura voltada à “[...] participação dos destinatários dos efeitos do ato final em sua fase preparatória; na simétrica paridade de suas posições; na mútua implicação de suas atividades [...]; na relevância das mesmas para o autor do provimento [...]"25,26, mediação penal somente alcança legitimidade - vista sob as lentes da justiça restaurativa - se os destinatários dos efeitos do ato final, no caso, a vítima, o ofensor e, quando o caso, também outros membros da comunidade, participem ativamente da tentativa de construção da medida de solução do conflito. Isso porque, tão importante como o conteúdo da medida acaso construída (ou não) ${ }^{27}$ é também que o processo de sua construção seja, de fato, coletivo e tenha como sujeitos principais os próprios destinatários, cabendo ao mediador o papel de facilitador do diálogo, no exato sentido do termo mediador.

Exatamente por isso é tão necessário reafirmar-se que a estrutura (tanto física, como instrumental e humana) necessária à implementação da mediação penal em Portugal precisou ser erguida do zero a partir da edição da Lei n. 21/2007 que a instituiu.

Afinal, uma aproximação dela em relação ao mecanismo da suspensão provisória do processo possa não apenas conduz o leitor em falsa pista acerca das bases daquela como

\footnotetext{
${ }^{25} \mathrm{Na}$ redação original, uma estrutura voltada à “[...] partecipazione dei destinatari degli effetti dell'atto finale alla fase preparatoria del medesimo, nella simmetrica parità dele loro posizioni; nella mutua implicazione delle loro attività [...]; nella rillevanza delle medesime per l'autore del provvedimento".

${ }^{26}$ FAZZALARI, Elio. Istituzioni di diritto processuale. 8. Ed. Milani: Padova, 1996, p. 83.

${ }^{27}$ Até porque, o fato de não se lograr êxito na construção de um acordo que ponha fim ao conflito não tira o mérito da mediação enquanto método alternativo em si e enquanto processo restaurativo. Nesse sentido, de clareza solar é a leitura que Cláudia Cruz Santos faz da Resolução ONU n. 2002/12, emitida por seu Conselho Econômico e Social, datada de 24 de julho de 2002 e que tem por objeto a especificação dos princípios básicos para a utilização de programas de justiça restaurativa em matéria criminal. Nas palavras dela, "Nesta Resolução, um programa de justiça restaurativa é apresentado como aquele que usa processos restaurativos e que vista atingir resultados restaurativos (elege-se, assim, uma definição centrada quer no procedimento, quer no resultado). Relativamente ao procedimento, esclarece-se que a vítima e o ofensor (assim como, quando adequado), outros membros da comunidade) deve 'participar activamente na resolução das questões oriundas do crime, geralmente com a ajuda de um facilitador'. Quanto ao resultado restaurativo, especifica-se que se trata de 'um acordo construído no processo restaurativo', o qual deve incluir 'respostas' como a 'reparação, a restituição e o serviço comunitário', tendo em conta as necessidades individuais e colectivas, a responsabilidade e a reintegração" (O direito processual penal português em mudança: rupturas e continuidades. Coimbra: Almedina, 2020, p. 146). Em semelhante sentido, Cristina Rego de oliveira sustenta que "[...] se a adoção de uma nova dinâmica de tratamento aos crimes praticados requer a aceitação dos legitimados (os sujeitos destinatários e o Ministério Público), faz-se essencial que os titulares participem, de alguma forma, da tomada de decisões, opinando acerca da temática." (Sobre o que a mediação penal (não) pode ser: uma abordagem crítica das práticas luso-brasileiras. Revista Jurídica do Ministério Público do Estado do Paraná, Curitiba, a. 2, n. 3, p. 2015, p. 84).
} 
também, e acima de tudo, acaba por viciar a atuação dos sujeitos quando da realização das práticas de mediação penal, levados por uma equivocada compreensão das dimensões do crime, da pena e do próprio consenso no campo do direito penal e do processo penal ${ }^{28}$, a entende-las - mediação penal e suspensão provisória do processo - como duas modalidades muito próximas de diversão processual.

E é nesse sentido que se pode - ou melhor, deve - dizer que a Lei n. 21/2007 não apenas introduziu o mecanismo da mediação penal no cenário português, como também que por meio dela se definiu, para os interessados, os requisitos para submissão de seus conflitos à mediação e, para o Estado, os requisitos para constituição do quadro de mediadores e seu padrão remuneratório, o papel do Ministério Público e outras questões técnico-operacionais ${ }^{29}$, iniciando-se a partir daí e do zero o sistema de mediação penal português.

Uma vez constituída a estrutura básica, a implementação das atividades de mediação penal em Portugal se deu de modo faseado a partir do ano de 2008 quando, nos termos da Portaria n. 68-C/2008 do Ministério da Justiça Português, passou a ser realizada a título experimental nas Comarcas do Porto, Aveiro, Oliveira do Bairro e Seixal. E no ano seguinte, por força da Portaria n. 732/2009, foi estendida às Comarcas de Barreiro, Braga, Cascais, Coimbra, Loures, Moita, Montijo, Santa Maria da Feira, Seixal, Setúbal, Vila Nova de Gaia, Alentejo Litoral, Baixo Vouga e Grande Lisboa Noroeste ${ }^{30}$. Desde então, passaram-se doze anos nos quais, ao menos formalmente, a mediação penal se apresenta como um método alternativo de solução de conflitos na seara penal ${ }^{31}$.

\footnotetext{
${ }^{28}$ Afirmação essa que fazemos novamente com apoio em Claudia Cruz Santos, segundo a qual "quando se compreende que o crime pode ter mais do que uma dimensão, compreende-se também que se devam abrir distintas possibilidades de resposta. Compreende-se a importância da resposta dada pela justiça penal àquela dimensão pública do crime e compreende-se que aí o papel da vítima não seja o principal. Mas compreendese também a necessidade de outras formas de resposta para aquela outra dimensão do crime, que é a dimensão interpessoal" (O direito processual penal português em mudança: rupturas e continuidades. Coimbra: Almedina, 2020, p. 166).

${ }^{29}$ Com base nos requisitos estabelecidos na Lei n. 21/2007, encontravam-se inscritos na lista do Sistema de Mediação Penal de Portugal em dezembro de 2019 (quando a informação foi prestada pelo GRAL), 71 mediadores, dos quais 1 formado em Antropologia, 1 em Educação e Intervenção Comunitária, 1 em engenharias das Construções Civis, 1 em Filosofia, 1 em Línguas e Literaturas Modernas, 7 em Psicologia, 1 em Psicologia e Direito e 58 em Direito.

${ }^{30}$ CAMPANÁRIO, Micaela Susana Nóbrega de Abreu. Mediação Penal. Cívitas, Porto Alegre, v. 13, n.1, jan-abr.2013, p. 119.

${ }^{31}$ Método esse que, por óbvio, nos termos da Lei n. 21/2007 não é permitido em todo e qualquer conflito penal, mas apenas àqueles que se enquadrem nos requisitos estabelecidos. Isto é, que se tratem de crimes privados e semipúblicos - que no direito brasileiro equivalem aos chamados crimes de ação penal privada e
} 
Dizemos ao menos formalmente porque, embora em um primeiro momento, entre os anos de 2008 e 2011 tenha se verificado uma tendência crescente de submissão de casos penais ao sistema de mediação penal, o que levava a crer que o mesmo estava por se consolidar no contexto mais amplo da estrutura de justiça penal portuguesa, curiosamente a partir de 2011 o número de casos encaminhados à mediação penal passou a cair vertiginosamente até que entre fins de 2016 e início de 2017 o sistema de mediação penal restou completamente esvaziado. De modo tal que, ao longo de todo o período, o recurso à mediação penal para a tentativa de solução do conflito penal se verificou em não mais que 803 infrações penais ${ }^{32}$. Levantamento esse feito junto ao Gabinete de Resolução Alternativa de Litígios do Ministério da Justiça de Portugal (GRAL) e cujos dados se encontram discriminados na Tabela 1 , ao final do trabalho.

E desse total de 803 casos, a maioria foi objeto de mediação penal nos primeiros anos de funcionamento do sistema, conforme facilmente se verifica a partir do Gráfico 1, presente ao final deste trabalho. O que confirma nossa afirmação acima de que a partir de 2011 a busca da mediação penal para solução dos conflitos penais foi paulatinamente abondada em Portugal.

\section{O papel do Ministério Público na mediação penal e a visão de seus membros sobre tal papel e sobre a própria mediação}

Ao final do tópico anterior mostramos que, apesar de um início bastante promissor, a partir do ano de 2011 paulatinamente a mediação penal foi sendo abandonada em Portugal e, desde 2017, nenhum caso foi encaminhado aos órgãos de mediação penal em Portugal ${ }^{33}$.

\footnotetext{
pública condicionada a representação, respectivamente, para os quais prevista pena máxima não superior a cinco anos, excluídos os crimes contra a liberdade sexual, os crimes de peculato, corrupção, tráfico de influência, aqueles cometidos contra vítima menor de 16 anos e ainda aqueles cujo processamento se dê sob os ritos sumário ou sumaríssimo (SILVA, Fernando Laércio Alves da; VERZELLONI, Luca. A mediação penal em Portugal doze anos depois: início, meio e fim(?). Revista de Informação Legislativa. Brasília, n. 227, jul-ago. 2020. No prelo.).

$32 \mathrm{O}$ número total de casos, bem como sua discriminação por tipo de infração penal nos foi fornecido diretamente pelo GRAL em 19 de dezembro de 2019, após consulta formal encaminhada em meados de novembro do mesmo ano por correio eletrônico.

${ }^{33}$ Como bem se verifica no Gráfico 1, presente ao final do trabalho.
} 
Diante desse cenário, necessário e urgente se faz identificar as causas desse abandono. E isso não por mera curiosidade acadêmica ${ }^{34}$, mas sim como um primeiro passo tanto para a prestação de contas à sociedade portuguesa e europeia, já que estamos falando em uma estrutura implantada por exigência da Comunidade Europeia e que custou consideráveis euros dos cofres públicos de Portugal, como também, e principalmente, para a identificação dos reparos necessários a sua retomada. Nesse sentido, algumas hipóteses foram levantadas e enfrentadas ao longo da investigação, as quais passam agora a ser apresentadas.

Uma primeira hipótese que se ventilou foi a de que o número de crimes no mesmo intervalo temporal teria sido tão baixo - e seu processamento facilmente absorvido pela via tradicional do sistema de justiça penal - que o recurso à mediação penal restou pouco atrativo. Afinal, tendo em conta os dados estatísticos que apontam Portugal como um dos países mais pacíficos e seguros do mundo, com índices de criminalidade muito baixos, tal hipótese não seria irrazoável ${ }^{35} \mathrm{e}$, portanto, não poderia ser refutada de plano.

Para esclarecimento acerca da validade ou não da hipótese, um dos caminhos mais seguros é o da verificação dos dados absolutos do sistema de justiça português. E uma leitura mais atenta desses dados absolutos feita em relação aos crimes que em tese ${ }^{36}$ poderiam ter sido encaminhados à mediação penal, mas que foram efetivamente processados e julgados pela justiça tradicional durante o mesmo intervalo temporal (20082018), no entanto, afasta tal hipótese ${ }^{37}$.

Isso porque, embora reste claro pela leitura desses dados que Portugal experimentou considerável redução do número de crimes ao longo da década 2008-2018, em termos absolutos ainda assim se percebe uma profunda discrepância entre o total de casos submetidos à mediação penal e aqueles submetidos à justiça penal tradicional.

\footnotetext{
${ }^{34} \mathrm{E}$ ainda que assim o fosse, problema algum veríamos já que o conhecimento pelo conhecimento não pode ser relegado a uma posição menos importante.

${ }^{35}$ Segundo dados apresentados no Global Peace Index 2020: measuring peace in a complex world, desde o ano de 2008, Portugal ocupa a posição de terceiro país mais pacífico em um ranking que integra 163 países dos cinco continentes, atrás apenas de Islândia e Nova Zelândia e imediatamente à frente de Áustria e Dinamarca, respectivamente. Nos termos do próprio Relatório, "Iceland remains the most peaceful country in the world, a position it has held since 2008. It is joined at the top of the index by New Zealand, Austria, Portugal, and Denmark" (INSTITUTE FOR ECONOMICS AND PEACE. Global Peace Index 2020: measuring peace in a complex world. Sidney, jun./2020., p. 02).

${ }^{36}$ Falamos em crimes que em tese poderiam ter sido encaminhados à mediação penal porque os dados apenas permitem identificar o número de crimes por tipo penal, sem qualquer análise de conteúdo em relação aos demais requisitos exigidos para a aplicabilidade da mediação penal no caso concreto.

${ }^{37}$ Os dados aqui mencionados encontram-se condensados na Tabela 2, ao final do trabalho.
} 
A segunda hipótese ventilada no início da investigação foi a de que a estruturação dos órgãos responsáveis pelo desenvolvimento da mediação - notadamente a composição e formação do quadro de mediadores - teria sido inadequada. O que, ainda no campo hipotético, poderia ter resultado em sua incapacidade de atender às demandas, levando a descrédito e consequente abandono o modelo lusitano de mediação penal.

Hipótese essa que restou afastada quando de leitura e análise dos documentos coletados, em especial trabalhos desenvolvidos por Cláudia Cruz Santos ${ }^{38}$, Micaela Campanário $^{39}$ e Fernando Laercio Alves da Silva e Luca Verzelloni ${ }^{40}$. Isso porque em todos esses trabalhos, em especial o último - que além de mais recente se volta a analisar aspectos próprios do quadro de mediadores penais em Portugal e sua relação com o GRAL e com o Ministério Público - concluiu-se, de um lado, que o quadro de mediadores penais constituído em Portugal se mostrava e ainda se mostra suficiente para absorver todos os casos encaminhados sem risco de atraso ou qualquer dificuldade de cumprimento do prazo máximo de três meses para conclusão das sessões de mediação e, de outro, que o índice de solução dos conflitos penais por meio da mediação se mostrou satisfatório.

Afastadas essas duas hipóteses, uma terceira hipótese levantada seria a de o número de casos de mediação penal em Portugal entrara em declínio simplesmente porque os responsáveis pelo envio dos mesmos aos mediadores, a dizer, os membros do Ministério Público competentes, em determinado momento teriam parado de o fazer.

Explicamos: nos termos da conformação legislativa da mediação penal portuguesa, o Ministério Público fora posicionado com especial importância, cabendo a seus membros - especificamente aqueles competentes para atuar nos casos penais concretos -, uma vez verificados o preenchimento dos requisitos mínimos, decidir, nos termos do art. $3^{\circ}$, n. 1 , da Lei n. 21/2007, decidir entre o seu encaminhamento à mediação penal - alimentando, portanto o sistema - ou prosseguir com a propositura da ação penal pela via do modelo tradicional de justiça penal ${ }^{41}$. A ponto, inclusive, de se poder atribuir a esse ator

\footnotetext{
${ }^{38}$ A justiça restaurativa - Um modelo de reacção ao crime diferente da Justiça Penal. Por quê, para quê e como? Coimbra: Coimbra Editora, 2014.

${ }^{39}$ Mediação Penal. Cívitas, Porto Alegre, v. 13, n.1, p. 118-135, jan-abr.2013.

40 A mediação penal em Portugal doze anos depois: início, meio e fim(?). Revista de Informação Legislativa. Brasília, n. 227, jul-ago. 2020. No prelo.

${ }^{41}$ É bem verdade que nos termos do art. $3^{\circ}$, item 2, da mesma Lei n. 21/2007 também autoriza ao ofendido e ao ofensor a iniciativa da solicitação da mediação penal. A experiência, no entanto, demonstrou serem raros
} 
processual, mais até que aos próprios mediadores, a maior parcela de responsabilidade seja pelo sucesso, seja pelo fracasso da mediação penal em Portugal $^{42}$.

Nesse contexto, inegável a plausibilidade da hipótese ventilada, tornando-se necessário investigá-la concretamente e, caso confirmada, averiguar os motivos de sua ocorrência.

E neste ponto, indispensável o recurso ao trabalho de Fernando Laercio Alves da Silva e Luca Verzelloni neste texto já citado e referenciado, no qual os autores, recorrendo à auscultação dos mediadores penais em Portugal e também do GRAL, obtiveram como resposta dos primeiros - os mediadores penais - a informação de que em determinado momento, simplesmente o Ministério Público parou de enviar casos para a mediação, notando-se falta de empenho seja do Ministério Público, seja do Ministério da Justiça na consolidação do sistema. E da então diretora do GRAL a informação de que aparentemente o Ministério Público teria deixado de acreditar na mediação enquanto modelo de resolução de conflitos penais ${ }^{43}$.

Para além, contudo, do simples recurso a investigações outras, diante do diagnóstico inicial de confirmação da hipótese, buscamos ratificá-la (ou não) através da auscultação do próprio órgão em questão: O Ministério Público de Portugal atuante na seara criminal. O que fizemos por meio da aplicação do questionário de que falamos na introdução deste texto.

E graças a essa auscultação, foram descortinadas algumas questões que até então estavam obscuras, ao menos para nós.

\footnotetext{
os casos de mediação assim iniciados, até mesmo por conta do desconhecimento público acerca de sua existência e possibilidade.

${ }^{42}$ Nesse sentido, ainda no ano de 2007, João Conde Correia assinalou que "O Ministério Público será, sem dúvida, um dos principais actores da mediação penal e, certamente, aquele que mais irá contribuir para o sucesso ou insucesso da medida. Desde logo, porque, na generalidade dos casos, será dele o impulso inicial da remessa dos autos para a mediação penal (art. $3^{\circ}$, n. 1) e porque, mesmo quando ela é pedida pelo ofendido e pelo arguido, compete-lhe fiscalizar a verificação dos respectivos pressupostos formais e materiais (art. $3^{\circ}$, n. 2). Depois, porque, para além deste impulso inicial, também será dele o juízo final sobre a bondade do resultado aí alcançado $\left(\operatorname{art.} 5^{\circ}, \mathrm{n} ; 5^{\circ}\right.$ ). Em ambos os casos (impulso oficial ou resultado final) impende, por isso, sobre o magistrado do Ministério Público uma difícil tarefa de avaliação, de ponderação e de decisão: ele está no princípio e no fim da mediação penal. Só as estratégias adoptadas com vista à obtenção de um acordo satisfatório para todos os intervenientes escapam ao seu juízo decisório." (O papel do Ministério Público no regime legal da mediação penal. Revista do Ministério Público. Lisboa, v. 98, n. 112, out.dez/2007, p. 57).

${ }^{43}$ A mediação penal em Portugal doze anos depois: início, meio e fim(?). Revista de Informação Legislativa. Brasília, n. 227, jul-ago. 2020. No prelo.
} 
A começar pela constatação de que a esmagadora maioria dos procuradores ouvidos jamais encaminhou algum caso penal ao sistema de mediação ${ }^{44}$ e sequer foi cobrado ou mesmo estimulado pela Procuradoria Geral da República para o fazer ${ }^{45}$. Longe disso, questionados se recordavam de atuação da PGR voltada ao estímulo e à orientação sobre a adequada aplicação da mediação penal como forma de solução de conflitos, apenas um dos entrevistados respondeu ter memória disso e outro respondeu que, embora não houvesse nenhuma orientação específica, a PGR incentivava a prática da mediação penal. Quanto aos demais entrevistados, ou responderam que não se recordavam ou que inexistia qualquer orientação da PGR.

Nesse mesmo sentido, questionados sobre a realização de cursos ou programas de formação e capacitação - o que indicaria uma política de formação e defesa do sistema de mediação penal por parte da PGR - as respostas obtidas não deixaram dúvidas de que, a despeito da eleição do Ministério Público como agente primordial para o desenvolvimento da mediação penal em Portugal na Lei n. 21/2007 - law in book - isso não se converteu em uma atuação concreta - law in action.

Tratando-se de uma estrutura completamente nova - e em grande parte desconhecida em Portugal, como mostramos de fato ser -, o primeiro passo tomado pelo Ministério Público português no sentido de sua passagem do plano da law in book para o de law in action consistiria em uma intensa formação de seus membros acerca tanto dos fundamentos teóricos da mediação penal ${ }^{46}$, como de sua identidade enquanto mecanismo alternativo de solução de $\operatorname{conflitos}^{47}$ e, por óbvio, das engrenagens para seu funcionamento e da responsabilidade do Ministério Público nesse sentido.

\footnotetext{
${ }^{44}$ Uma das perguntas formuladas aos inquiridos foi se "no âmbito de sua atuação, já encaminhou casos para busca de solução pelo sistema de mediação penal?", à qual $81,3 \%$ dos entrevistados responderam negativamente.

45 Uma das perguntas formuladas foi se "houve alguma cobrança por parte dos órgãos superiores do Ministério Público para o envio de casos para a mediação penal”, à qual 81,3\% dos entrevistados respondeu jamais ter sido questionado ou cobrado nesse sentido, $12,5 \%$ respondeu ter sido questionado alguma vez $\mathrm{e}$ apenas $6,2 \%$ respondeu ter sido questionado mais de uma vez sobre os motivos para o não envio de casos à mediação penal.

${ }^{46}$ Tanto no que diz respeito a suas bases científico-filosóficas, ancoradas nas teorias da justiça restaurativa, da vitimologia.

${ }^{47}$ Sob uma perspectiva cappellettiana.
} 
Por meio do questionário aplicado, constatamos, no entanto, que essa formação não foi promovida. $\mathrm{Ou}$, se o foi, tratou-se de uma medida tão local e limitada no tempo que sequer é lembrada pelos entrevistados ${ }^{48}$.

O que acaba por influenciar diretamente em sua visão acerca da mediação penal e, consequentemente, na pouca disposição ou baixo grau de confiança nela para solução alternativa de conflitos penais. Isso ao menos em relação aos membros do Ministério Público português que participaram da pesquisa na condição de entrevistados. O que constatamos a partir das respostas apresentadas a outras perguntas que integraram o questionário aplicado que foram formuladas especificamente aos entrevistados que em momento anterior do questionário aplicado informaram jamais ter enviado casos sob sua responsabilidade para a mediação penal.

Chamou-nos a atenção o fato de $25 \%$ dos entrevistados enquadrados nessa situação terem informado que o sistema de mediação penal já não funcionava quando de seu ingresso. Isso porque essa resposta entra em choque com o que informaram quando questionados sobre o tempo de ingresso no Ministério Público, uma vez que à exceção de um entrevistado que informou estar há menos de 05 anos nos quadros funcionais do órgão, todos os demais contam com mais tempo de atuação funcional - entre os quais, $12,5 \%$ informaram tempo de membro do Ministério Público variante entre 05 e 10 anos, 25\% entre 10 e 15 anos, $12,5 \%$ entre 15 e 20 anos e 43,8\% contando com mais de 20 anos de atividade. $\mathrm{O}$ que torna estranha a afirmação de que o sistema de mediação penal já não funcionava quando de seu ingresso.

Retornando ao questionamento acerca dos motivos pelos quais teriam deixado de encaminhar casos sob sua responsabilidade para a mediação penal, os demais entrevistados

\footnotetext{
${ }^{48}$ Uma das questões apresentadas aos entrevistados destinava-se a verificar se participaram de alguma formação que tivesse as teorias da justiça restaurativa como temática central, à qual metade dos entrevistados negativamente. $E$ entre os que responderam afirmativamente, questionados em sequência se a formação teria sido suficiente para a compreensão dos fundamentos da justiça restaurativa, a maioria ( $75 \%$ desse grupo ou $37,5 \%$ do total de entrevistados) respondeu que apenas parcialmente. Foram também questionados sobre a participação em cursos de formação sobre o pensamento de Mauro Cappelletti e as ondas de acesso à justiça, conhecimento indispensável a quem se dispõe a trabalhar como métodos alternativos de solução de conflitos. À pergunta, os entrevistados foram unânimes em responder jamais terem participado de qualquer formação nesse sentido. Ainda nesse sentido, foram os investigados questionados sobre a participação em cursos de formação específicos sobre o tema da mediação penal e, em caso afirmativo, se tal formação se mostrava suficiente para prepará-los ao trabalho com tal sistema. Ao primeiro tópico - participação em cursos de formação sobre mediação penal - 56,3\% dos entrevistados responderam negativamente, e entre os $43,7 \%$ que participaram de formação sobre esse tema, a maioria indicou a formação como insuficiente (18,8\% do total de entrevistados) ou parcialmente suficiente (37,5\% do total de entrevistados) para capacitá-los.
} 
assim se manifestaram: $25 \%$ deles confessaram não acreditar no modelo para a solução de conflitos penais e os $50 \%$ restantes disseram que nenhum caso sob sua responsabilidade se enquadrava nos critérios para envio.

Respostas essas que sinalizam graves descompassos no pós-edição da Lei n. 21/2007 e confirmam a ausência/deficiência da formação dos membros do Ministério Público acerca da mediação penal.

Não é o caso, por óbvio, de se supor que todas as pessoas que conhecem os fundamentos e o método de funcionamento da mediação penal inevitavelmente venham a tornar-se seus ferrenhos e engajados defensores. Trata-se, isto sim, de identificar nessa ausência/deficiência de formação um obstáculo a que sequer tenham condição para formar um juízo crítico verdadeiro sobre o instituto. E diante da impossibilidade de formação desse juízo crítico, os únicos caminhos que se colocam como possíveis são o da incredulidade ou o da não identificação de elementos concretos autorizadores da aplicação do instituto.

Afinal, entre o novo (e, principalmente, desconhecido) modelo de solução de conflitos penais por meio da mediação e o antigo e já sedimentado modelo embasado na justiça retributiva, dentro do qual a integralidade dos membros do Ministério Público de Portugal (assim como a quase totalidade dos operadores do direito penal em uma matriz cultural sustentada na perspectiva da tradição jurídica continental europeia), salvo na hipótese de um profundo processo de capacitação e treinamento, dificilmente se optaria pelo primeiro.

O que acreditamos ter sido confirmado a partir da resposta obtida a outra das questões aplicadas. Isso porque, questionados se seriam favoráveis adoção de nova postura de estímulo ao recurso à mediação penal por parte do Estado de Portugal, 56,3\% dos entrevistados se manifestou favoravelmente, entendendo que o estímulo inicialmente adotado não foi suficiente à concretização da medida dentro do sistema de justiça.

\section{0 que será o amanhã? Responda quem puder...}

Não cabe a nós a realização de qualquer exercício de futurologia. Aliás, o objetivo da pesquisa - desde o início apresentado de modo claro - era o de verificar se a visão dos 
membros do Ministério Público Português em relação à mediação figura entre as causas de seu abandono. Verificação que conduzimos por meio tanto da pesquisa documental como também da própria auscultação de membros do Ministério Público.

E o final da investigação, nos parece claro - ao menos tendo em conta para nossa conclusão a amostra de dados colhida - que, de fato, a visão dos membros do Ministério Público sobre a mediação penal deve ser considerada como uma das principais (senão a principal) causas para o insucesso (ainda que momentâneo) da tentativa de implantação da mediação penal em Portugal.

O que não significa, e isso deve ser dito de modo enfático para evitarmos qualquer equívoco de comunicação ou de interpretação, que se devam lançar pedras contra os membros do Ministério Público de Portugal ou mesmo tachá-los negativamente. Longe disso, o que a investigação também nos permitiu concluir foi que, de modo geral tanto a visão negativa que os membros do Ministério Público de Portugal tem sobre a mediação penal, compreendendo-a como não adequada enquanto resposta nos conflitos penais ou mesmo não sabendo identificar sua viabilidade ou não no caso concreto decorre sobretudo de uma deficiência formativa.

Deficiência essa não apenas em relação ao instituto da mediação penal em si ou das novas formas alternativas de resolução de conflitos, como também acerca do próprio processo de metamorfose pelo qual o sistema de justiça penal tem passado tanto em Portugal e como nos demais Estados de tradição jurídica continental, restando inevitavelmente presos em suas bolhas e restritos a um saber aplicar o direito que em muitos aspectos se encontra ultrapassado e em descompasso com a realidade discursivodemocrática que se pretende firmar como paradigmática neste século $\mathrm{XXI}^{49}$.

Um saber aplicar o direito que ainda se sustenta na ideia ultrapassada de que o processo judicial seria "[...] técnica única e universal para solucionar os diferendos." 50

\footnotetext{
49 Sobre essa questão, uma melhor densificação pode ser obtida a partir da leitura dos escritos de Sara Alexandre Domingues Araújo, onde a autora bem desenvolve a reflexão de que "o problema da modernidade não é a sua raiz ocidental, mas sim o legado iluminista e a impossibilidade de cumprir as promessas de universalidade contidas nos ideais do iluminismo." (Ecologias de justiças a Sul e a Norte: Cartografias comparadas das justiças comunitárias em Maputo e Lisboa, 2014542 f. Tese (Doutorado) - Universidade de Coimbra, Programa de Doutoramento em Direito, Justiça e Democracia no Século XXI, da Faculdade de Economia, p. 38).

${ }^{50}$ PEDROSO, João TRNCÃO, Catarina, DIAS, João Paulo. Por caminho(s) da(s) reforma(s) da Justiça. Coimbra: Coimbra Editora, 2013, p. 205.
} 
Saber esse que não pode ser superado senão por meio de um profundo trabalho de esclarecimento e formação cuja falta, reafirma-se, identificamos ${ }^{51}$.

Daí que, embora tenhamos alcançado nosso objetivo de identificar algumas das possíveis causas do insucesso da tentativa de implementação do sistema de mediação penal em Portugal, entre as quais salta aos olhos como uma das principais a inércia do Ministério Público em cumprir as funções que lhe foram estabelecidas na Lei n. 21/2007 - inércia essa que identificamos não como um comportamento livre e deliberado, mas como consequência direta da ausência de um programa de formação e atualização em favor de seus membros - na atual quadra histórica não nos vemos em condição de afirmar categoricamente qual o futuro da mediação penal em Portugal.

Embora de um lado se tenha toda a estrutura estabelecida, aguardando a retomada das atividades, não pode ela ser feita a fórceps, exigindo que se cumpra aquilo que desde o início tem faltado: a formação dos membros do Ministério Público. E isso não depende deste ou de qualquer outro investigador ou centro de pesquisa individualmente, aos quais cabe apenas deixar o alerta de que se trata de uma política pública estatal urgente e necessária $^{52}$.

Se o alerta será ouvido dentro de um futuro próximo ou não, responda quem puder.

\footnotetext{
${ }^{51}$ Em semelhante sentido, António Manuel Hespanha em preciosas e precisas palavras, esclarece que "Esta versão comum (republicana, da respublica no seu conjunto) do direito tem que assentar numa observação complexa e dialogada das nossas sociedades e das narrativas jurídicas nela vigentes, no modo como elas têm sido construídas, na natureza (leal ou enviesada) dos consensos sobre que assentam. Em todo o processo as capacidades de observar sem preconceitos e de perceber a complexidade do que se observa são centrais. E, a partir deste diagnóstico, tem que se ir avaliando da legitimidade de cada versão setorial do direito, afinando cada uma delas por meio de consensos mais refletidos e mais justos e, ao fim, compondo tudo num modelo em que os créditos de cada versão do direito dependam do modo como ela demonstra capacidade de ter em conta as outras e de se integrar num modelo que articule consensualmente todas as outras. Não se trata de um processo rápido, nem suscetível de ser levado a cabo exclusivamente por juristas com recursos aos seus saberes especializados. Muito pelo contrário. Trata-se de um lento processo de experimentação, erro e correção. No qual nem sequer é certo que os juristas desempenhem um papel de protagonistas, porque, como se verá, muitos dos saberes usuais dos juristas poderão constituir antes obstáculos do que instrumentos úteis. Sobretudo porque aquilo que eles têm por assento e que frequentemente, resistem a repensar, faz parte de um saber datado, com mais de dois séculos de idade, referido a um modelo de poder que não é o de hoje, demasiado autoconfiante e profundamente elitista." (Pluralismo jurídico e direito democrático: prospectivas do direito no século XXI. Coimbra: Almedina, 2019, p. 16)

${ }^{52}$ Afinal, como bem esclarece João Paulo Dias, O Ministério Público é um ator crucial no sistema de acesso ao direito e à justiça, intervindo nos mais variados domínios. Todavia, o seu desempenho e a sua capacidade de adaptação às transformações que estão a ocorrer na área da justiça (participando ativamente nos processos de decisão) são fundamentais para definir as suas futuras competências e práticas profissionais (formais e informais) e o seu grau de participação no sistema integrado de acesso ao direito e à justiça, em que múltiplas entidades, judiciais e não judiciais, contribuem para estabelecer um mosaico de possibilidades de prestação de apoio aos cidadãos." (Desafios ao Ministério Público em Portugal: porta de entrada para a cidadania.
} Revista de Sociologia Configurações, Coimbra, n. 13, p. 27-46, 2014, p. 12). 


\section{REFERÊNCIAS}

ALMEIDA, Carlota Pizarro de. A propósito da decisão-quadro do Conselho de 15 de Março de 2001: algumas considerações (e interrogações) sobre a mediação penal. Revista Portuguesa de Ciência Criminal, Coimbra, ano 15, n. 3, p. 391-414, julset.2005.

ARAÚJO, Sara Alexandre Domingues. Ecologias de justiças a Sul e a Norte: Cartografias comparadas das justiças comunitárias em Maputo e Lisboa, $2014542 \mathrm{f}$. Tese (Doutorado) - Universidade de Coimbra, Programa de Doutoramento em Direito, Justiça e Democracia no Século XXI, da Faculdade de Economia.

BARROS, Flaviane de Magalhães. O processo, a jurisdição e a ação sob a ótica de Elio Fazzalari. Revista Eletrônica da Faculdade Mineira de Direito, Belo Horizonte, v. 1, ano 2, p. 01-29, 2003. Disponível em <http://webcache.googleusercontent.com/search?q=cache:8q0IEybq6oQJ:www.fmd. pucminas.br/Virtuajus/Ano2_08_2003_arquivos/Docente/O\%2520PROCESSO,\%25 20A\%2520JURISDI\%25C7\%25C3O $\% 2520 \mathrm{E} \% 2520 \mathrm{~A} \% 2520 \mathrm{~A} \% 25 \mathrm{C} 7 \% 25 \mathrm{C} 3 \mathrm{O} \% 25$ 20SOB\%2520A\%2520\%25D3TICA\%2520DE\%2520ELIO\%2520FAZZALARI.doc $+\& \mathrm{~cd}=4 \& \mathrm{hl}=\mathrm{pt}-\mathrm{BR} \& \mathrm{ct}=\mathrm{clnk} \& \mathrm{gl}=\mathrm{br}>$. Acesso em 20.dez.2016.

CAMPANÁRIO, Micaela Susana Nóbrega de Abreu. Mediação Penal. Cívitas, Porto Alegre, v. 13, n.1, p. 118-135, jan-abr.2013.

CAPPELlETTI, Mauro; GARTH, Bryant. Acesso à Justiça. Tradução de Ellen Gracie Northfleet. Porto Alegre: Sergio Antônio Fabris, 1988.

CARMO, Rui do. Um exercício de leitura do regime jurídico da mediação penal. Revista Portuguesa de Ciência Criminal, Coimbra, ano 20, n. 3, p. 451-476, jul-set. 2010.

CORREIA, João Conde. O papel do Ministério Público no regime legal da mediação penal. Revista do Ministério Público. Lisboa, v. 98, n. 112, p. 57-78, out.-dez/2007.

DIAS, João Paulo. O ministério público no acesso ao direito e à justiça: "porta de entrada" para a cidadania. Coimbra: Almedina/Centro de Estudos Sociais da Universidade de Coimbra, 2013.

DIAS, João Paulo. Desafios ao Ministério Público em Portugal: porta de entrada para a cidadania. Revista de Sociologia Configurações, Coimbra, n. 13, p. 27-46, 2014.

DIREÇÃO-GERAL DA POLÍTICA DE JUSTIÇA. Estatísticas da Justiça. Disponível em: 〈https://estatisticas.justica.gov.pt/sites/siej/pt-pt〉. Acesso em: 20 set. 2019. 


\section{DIREÇÃO-GERAL DA POLÍTICA DE JUSTIÇA. Lista de Mediadores do Sistema de Mediação Penal. Disponível em: <https://dgpj.justica.gov.pt/Portals/31/GRAL_Media\%E7\%E3o/Lista_mediadores_S MP_24.02.2020.pdf>. Acesso em: 15 fev. 2020.}

FAZZALARI, Elio. Istituzioni di diritto processuale. 8. Ed. Milani: Padova, 1996.

FRADE, Catarina. A resolução alternativa de litígios e o acesso à justiça: a mediação do sobreendividamento. Revista Crítica de Ciências Sociais, Coimbra, n. 65, p. 107128 , mai/2003.

HESPANHA, António Manuel. Pluralismo jurídico e direito democrático: prospectivas do direito no século XXI. Coimbra: Almedina, 2019.

INSTITUTE FOR ECONOMICS AND PEACE. Global Peace Index 2020: measuring peace in a complex world. Sidney, jun./2020. Disponível em <http://visionofhumanity.org/reports>. Acesso em 15.jul.2020.

LHUILLIER, Julien. The quality of penal mediation in Europe. In: Working Group on Mediation of European Commission for the Efficiency of Justice. Strasbourg: Concil of Europe, 22. ago.2007. Disponível em <http://www.antoniocasella.eu/restorative/Lhuillier_22aug2007.pdf $>$. Acesso em 22. abr. 2020.

OLIVEIRA, Cristiano Lessa de. Um apanhado teórico-conceitual sobre a pesquisa qualitativa: tipos, técnicas e características. Revista Travessias, Cascavel, v. 2, n. 3, p. 1-16, 2008.

PEDROSO, João TRNCÃO, Catarina, DIAS, João Paulo. Por caminho(s) da(s) reforma(s) da Justiça. Coimbra: Coimbra Editora, 2013.

PORTUGAL. Assembleia da República. Proposta de Lei n. 107-X, de 29 de novembro de 2006, de autoria do Governo. Disponível em: <https://www.parlamento.pt/ActividadeParlamentar/Paginas/DetalheIniciativa.aspx? $\mathrm{BID}=33326>$. Acesso em: 20. set. 2019.

PORTUGAL. Reunião plenária de 21 de fevereiro de 2007. Diário da Assembleia da República, X Legislatura 2. ${ }^{a}$ Sessão Legislativa (2006-2007), Lisboa, $22 \mathrm{de}$ fevereiro de 2007, I série, n. 51, p. 37-50.

PORTUGAL. Portaria n. 68-C, de 22 de janeiro de 2008. Disponível em <http://www.pgdlisboa.pt/leis/lei_mostra_articulado.php?nid=1500\&tabela=leis>. Acesso em 15.jul.2018.

PORTUGAL. Portaria n. 732, de 08 de julho de 2009. Disponível em <http://www.pgdlisboa.pt/leis/lei_mostra_articulado.php?nid=1500\&tabela=leis>. Acesso em 15.jul.2018. 
PROCURADORIA GERAL DISTRITAL DE LISBOA. Portaria n. ${ }^{\mathbf{6}}$ 6-C/2008, de 22 de janeiro: Regulamento do Sistema de Mediação Penal. Disponível em: <http://www.pgdlisboa.pt/leis/lei_mostra_articulado.php?nid=1500\&tabela=leis>. Acesso em: 20 jan. 2020.

REGO DE OLIVEIRA, Cristina. Sobre o que a mediação penal (não) pode ser: uma abordagem crítica das práticas luso-brasileiras. Revista Jurídica do Ministério Público do Estado do Paraná, Curitiba, a. 2, n. 3, p. 51-97.

SANTOS, Cláudia Cruz. A justiça restaurativa - Um modelo de reacção ao crime diferente da Justiça Penal. Por quê, para quê e como? Coimbra: Coimbra Editora, 2014.

SANTOS, Cláudia Cruz. O direito processual penal português em mudança: rupturas e continuidades. Coimbra: Almedina, 2020.

SILVA, Fernando Laércio Alves da. Processo Constitucional: o processo como locus devido para o exercício da democracia. Revista Eletrônica de Direito Processual, Rio de Janeiro, v. 16, n. 16, p. 157-188, jul-dez.2015.

SILVA, Fernando Laércio Alves da. Da neoinquisitoriedade à democracia: bases para o estabelecimento de um novo standard comportamental para os sujeitos no processo penal brasileiro. 2017390 f. Tese (Doutorado) - Pontifícia Universidade Católica de Minas Gerais, Programa de Pós-Graduação em Direito.

SILVA, Fernando Laércio Alves da; VERZELLONI, Luca. A mediação penal em Portugal doze anos depois: início, meio e fim(?). Revista de Informação Legislativa. Brasília, n. 227, jul-ago. 2020. No prelo.

SILVA, Fernando Laércio Alves da; COLLI, Luciene Rinaldi. Breves análises sobre a proposta de redução da idade penal. Revista de Direito (Viçosa). Viçosa, v. 1, n. 2, 2004, p. 37-56.

\section{TABELAS E GRÁFICOS}

\begin{tabular}{|c|c|c|c|}
\hline \multicolumn{4}{|c|}{ Casos submetidos a mediação penal em Portugal } \\
\hline Tipo penal & Descrição do delito & $\mathbf{N}^{\circ}$ de casos & $\%$ \\
\hline Art. 143, do CP & Ofensa à integridade física simples & 433 & 53,9 \\
\hline Art. 148 , do CP & Ofensa à integridade física por negligência & 9 & 1,1 \\
\hline Art. 153 , do CP & Ameaça & 86 & 10,7 \\
\hline Art. 154 , n. 4 , do CP & Coacção & 3 & 0,4 \\
\hline Art. 180 , do CP & Difamação & 10 & 1,3 \\
\hline
\end{tabular}


Revista Eletrônica de Direito Processual - REDP

Rio de Janeiro. Ano 15. Volume 22. Número 1. Janeiro a Abril de 2021

Periódico Quadrimestral da Pós-Graduação Stricto Sensu em Direito Processual da UERJ

Patrono: José Carlos Barbosa Moreira (in mem.). ISSN 1982-7636. pp. 322-349 www.redp.uerj.br

\begin{tabular}{|c|c|c|c|}
\hline Art. 181, do CP & Injúria & 30 & 3,7 \\
\hline Art. 183 , do CP & Publicidade e calúnia & 1 & 0,1 \\
\hline Art. 190 , do CP & Violação de domicílio ou perturbação da vida privada & 6 & 0,8 \\
\hline Art. 191, do CP & Introdução em lugar vedado ao público & 3 & 0,4 \\
\hline Art. 194, do CP & Violação de correspondência ou de telecomunicações & 1 & 0,1 \\
\hline Art. 203 , do CP & Furto simples & 66 & 8,2 \\
\hline Art. 205, do CP & Abuso de confiança & 28 & 3,5 \\
\hline Art. 209 , do CP & Apropriação ilegítima em caso de acessão ou de coisa achada & 4 & 0,5 \\
\hline Art. 212, do CP & Dano & 75 & 9,3 \\
\hline Art. 215 , do CP & Usurpação de coisa imóvel & 1 & 0,1 \\
\hline Art. 217, do CP & Burla & 28 & 3,5 \\
\hline Art. 219 , do CP & Burla relativa a seguros & 2 & 0,3 \\
\hline Art. 220 , do CP & Burla para obtenção de alimentos, bebidas ou serviços & 5 & 0,6 \\
\hline Art. 221 , do CP & Burla informática e nas comunicações & 2 & 0,3 \\
\hline $\begin{array}{l}\text { Art. 11, do Decreto- } \\
\text { Lei n. 454/1991, } \\
\text { alterado pelo } \\
\text { Decreto-Lei n. } \\
317 / 1997\end{array}$ & Emissão de cheque sem provisão & 10 & 1,2 \\
\hline \multicolumn{2}{|l|}{ Total de casos } & 803 & 100 \\
\hline
\end{tabular}

Tabela 1: Casos submetidos a mediação penal em Portugal (2008-2018) ${ }^{53}$

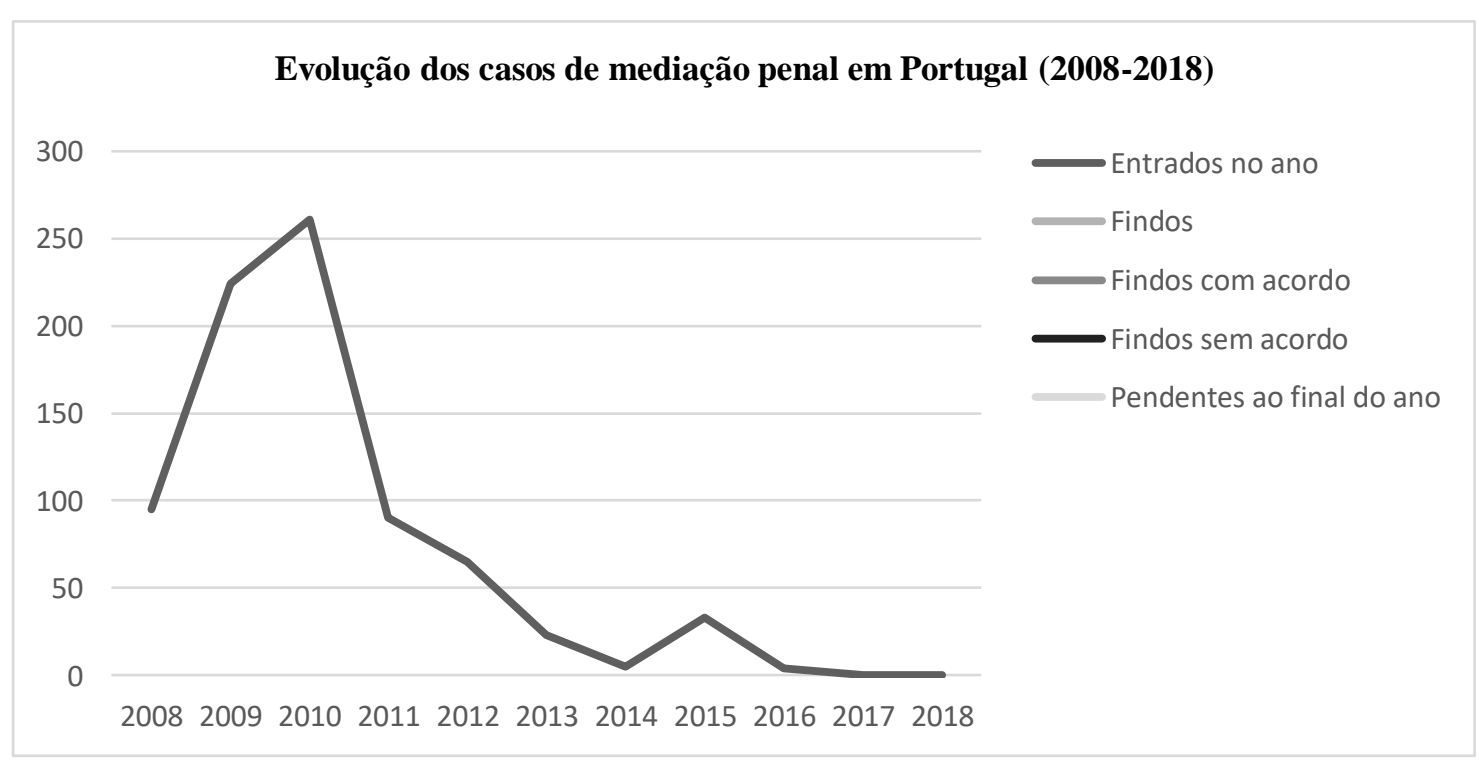

Gráfico 1: Evolução dos casos de mediação penal em Portugal (2008-2018) ${ }^{54}$

\footnotetext{
${ }^{53}$ Tabela extraída de SILVA, Fernando Laércio Alves da; VERZELLONI Luca. A mediação penal em Portugal doze anos depois: início, meio e fim(?). Revista de Informação Legislativa. Brasília, n. 227, julago. 2020. No prelo).
} 
Rio de Janeiro. Ano 15. Volume 22. Número 1. Janeiro a Abril de 2021

Periódico Quadrimestral da Pós-Graduação Stricto Sensu em Direito Processual da UERJ

Patrono: José Carlos Barbosa Moreira (in mem.). ISSN 1982-7636. pp. 322-349

www.redp.uerj.br

54 Extraído de SILVA, Fernando Laércio Alves da; VERZELLONI Luca. A mediação penal em Portugal doze anos depois: início, meio e fim(?). Revista de Informação Legislativa. Brasília, n. 227, jul-ago. 2020. No prelo). 
Revista Eletrônica de Direito Processual - REDP

Rio de Janeiro. Ano 15. Volume 22. Número 1. Janeiro a Abril de 2021

\begin{tabular}{|c|c|c|c|c|c|c|c|c|c|c|c|c|c|}
\hline \multirow[t]{2}{*}{$\begin{array}{c}\text { Tipo } \\
\text { penal }\end{array}$} & \multicolumn{13}{|c|}{ 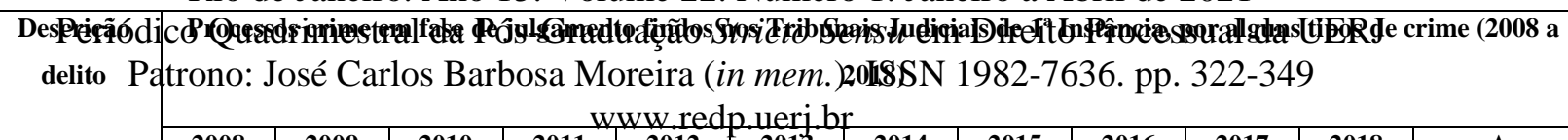 } \\
\hline & & & & & & & & & & & & & $=\begin{array}{c}\Delta \\
08.18\end{array}$ \\
\hline $\begin{array}{l}\text { Art. } \\
143, \text { do } \\
\text { CP }\end{array}$ & $\begin{array}{l}\text { Ofensa à } \\
\text { integridade } \\
\text { física } \\
\text { simples }\end{array}$ & 11.795 & 9.910 & 9.422 & 9.239 & 8.792 & 8.400 & 6.220 & 6.716 & 6.322 & 5.810 & 5.263 & -6.532 \\
\hline $\begin{array}{c}\text { Art. } \\
148, \text { do } \\
\text { CP }\end{array}$ & $\begin{array}{c}\text { Ofensa à } \\
\text { integridade } \\
\text { física por } \\
\text { negligência }\end{array}$ & 947 & 857 & 682 & 619 & 568 & 553 & 439 & 467 & 395 & 375 & 368 & -579 \\
\hline $\begin{array}{l}\text { Arts. } \\
153, \text { do } \\
\text { CP }\end{array}$ & Ameaça & 2.491 & 2.159 & 1.969 & 2.113 & 2.129 & 1.938 & 1.498 & 1.754 & 1.833 & 1.677 & 1.438 & -1.053 \\
\hline $\begin{array}{l}\text { Art. } \\
154, \text { do } \\
\text { CP }\end{array}$ & Coacção & 290 & 277 & 269 & 304 & 324 & 350 & 258 & 281 & 421 & 382 & 304 & +14 \\
\hline $\begin{array}{l}\text { Art. } \\
180, \text { do } \\
\text { CP }\end{array}$ & Difamação & 988 & 856 & 800 & 797 & 749 & 689 & 519 & 677 & 660 & 640 & 578 & -410 \\
\hline $\begin{array}{c}\text { Art. } \\
181 \text {, do } \\
\text { CP }\end{array}$ & Injúria & 2.464 & 2.077 & 1.969 & 1.860 & 1.818 & 1.697 & 1.296 & 1.412 & 1.414 & 1.318 & 1.158 & -1.306 \\
\hline $\begin{array}{c}\text { Art. } \\
183 \text {, do } \\
\text { CP }\end{array}$ & $\begin{array}{c}\text { Publicidade } \\
\text { e calúnia }\end{array}$ & 18 & 7 & 10 & 10 & 11 & 12 & 14 & 21 & 15 & 19 & 14 & -4 \\
\hline $\begin{array}{l}\text { Art. } 190 \\
\text { e } 191 \text {, } \\
\text { do CP }\end{array}$ & $\begin{array}{c}\text { Violação de } \\
\text { domicílio ou } \\
\text { perturbação } \\
\text { da vida } \\
\text { privada } \\
\text { /Introdução } \\
\text { em lugar } \\
\text { vedado ao } \\
\text { público }\end{array}$ & 317 & 275 & 246 & 254 & 266 & 289 & 223 & 251 & 240 & 237 & 178 & -139 \\
\hline $\begin{array}{c}\text { Art. } \\
194 \text {, do } \\
\text { CP }\end{array}$ & $\begin{array}{l}\text { Violação de } \\
\text { correspondê } \\
\text { ncia ou de } \\
\text { telecomunic } \\
\text { ações }\end{array}$ & 15 & 12 & 11 & 9 & 7 & 10 & 10 & 8 & 8 & 5 & 6 & -9 \\
\hline $\begin{array}{c}\text { Art. } \\
\text { 203, do } \\
\text { CP }\end{array}$ & $\begin{array}{c}\text { Furto } \\
\text { simples }\end{array}$ & 4.326 & 4.036 & 3.934 & 4.104 & 4.270 & 3.883 & 2.661 & 2.991 & 2.831 & 2.660 & 2.472 & -1.854 \\
\hline $\begin{array}{c}\text { Art. } \\
\text { 205, do } \\
\text { CP }\end{array}$ & $\begin{array}{l}\text { Abuso de } \\
\text { confiança }\end{array}$ & 1.021 & 826 & 868 & 885 & 968 & 955 & 743 & 848 & 844 & 844 & 648 & -373 \\
\hline
\end{tabular}


Revista Eletrônica de Direito Processual - REDP

Rio de Janeiro. Ano 15. Volume 22. Número 1. Janeiro a Abril de 2021

Periódico Quadrimestral da Pós-Graduação Stricto Sensu em Direito Processual da UERJ

Patrono: José Carlos Barbosa Moreira (in mem.). ISSN 1982-7636. pp. 322-349 www.redp.uerj.br

\begin{tabular}{|c|c|c|c|c|c|c|c|c|c|c|c|c|c|}
\hline $\begin{array}{c}\text { Art. } \\
209, \text { do } \\
\text { CP }\end{array}$ & $\begin{array}{c}\text { Apropriação } \\
\text { ilegítima em } \\
\text { caso de } \\
\text { acessão ou } \\
\text { de coisa } \\
\text { achada }\end{array}$ & 57 & 71 & 58 & 60 & 68 & 80 & 63 & 72 & 103 & 104 & 110 & +53 \\
\hline $\begin{array}{c}\text { Art. } \\
212 \text {, do } \\
\text { CP }\end{array}$ & Dano & 1.612 & 1.396 & 1.230 & 1.279 & 1.342 & 1.223 & 932 & 967 & 961 & 904 & 727 & -885 \\
\hline $\begin{array}{c}\text { Art. } \\
215 \text {, do } \\
\text { CP }\end{array}$ & $\begin{array}{c}\text { Usurpação } \\
\text { de coisa } \\
\text { imóvel }\end{array}$ & 13 & 9 & 16 & 14 & 9 & 9 & 5 & 5 & 10 & 5 & 4 & -9 \\
\hline $\begin{array}{c}\text { Art. } \\
217, \text { do } \\
\text { CP }\end{array}$ & Burla & 710 & 603 & 586 & 620 & 700 & 799 & 692 & 917 & 1.025 & 1.132 & 1.029 & 319 \\
\hline $\begin{array}{c}\text { Art. } \\
219, \text { do } \\
\text { CP }\end{array}$ & $\begin{array}{c}\text { Burla } \\
\text { relativa a } \\
\text { seguros }\end{array}$ & 12 & 7 & 6 & 10 & 6 & 4 & 4 & 4 & 4 & 6 & 1 & -11 \\
\hline $\begin{array}{c}\text { Art. } \\
220, \text { do } \\
\text { CP }\end{array}$ & $\begin{array}{c}\text { Burla para } \\
\text { obtenção de } \\
\text { alimentos, } \\
\text { bebidas ou } \\
\text { serviços }\end{array}$ & 158 & 111 & 80 & 68 & 60 & 90 & 48 & 47 & 51 & 48 & 37 & -121 \\
\hline $\begin{array}{c}\text { Art. } \\
221, \text { do } \\
\text { CP }\end{array}$ & $\begin{array}{c}\text { Burla } \\
\text { informática } \\
\text { e nas } \\
\text { comunicaçõ } \\
\text { es }\end{array}$ & 147 & 148 & 143 & 200 & 260 & 321 & 245 & 310 & 285 & 304 & 236 & +89 \\
\hline $\begin{array}{c}\text { Art. 11, } \\
\text { do } \\
\text { Decreto } \\
\text {-Lei n. } \\
454 / 199 \\
1, \\
\text { alterado } \\
\text { pelo } \\
\text { Decreto } \\
\text {-Lei n. } \\
317 / 199 \\
7\end{array}$ & $\begin{array}{c}\text { Emissão de } \\
\text { cheque sem } \\
\text { provisão }\end{array}$ & 3.755 & 2.211 & 1.921 & 1.806 & 1.439 & 1.734 & 774 & 637 & 412 & 385 & 238 & -3.517 \\
\hline & & 31.136 & 25.848 & 24.220 & 24.251 & 23.786 & 23.036 & 16.644 & 18.385 & 17.834 & 16.855 & 14.809 & \\
\hline Tota & de casos & 31.136 & 25.848 & 24.220 & 24.251 & 23.786 & 23.036 & 16.644 & 18.385 & 17.834 & 16.855 & 14.809 & \\
\hline
\end{tabular}


Revista Eletrônica de Direito Processual - REDP

Rio de Janeiro. Ano 15. Volume 22. Número 1. Janeiro a Abril de 2021

Periódico Quadrimestral da Pós-Graduação Stricto Sensu em Direito Processual da UERJ

Patrono: José Carlos Barbosa Moreira (in mem.). ISSN 1982-7636. pp. 322-349

www.redp.uerj.br

Tabela 2: Processos findos nos Tribunais Judiciais de $1^{\text {a }}$ Instância (2008 a 2018) ${ }^{55}$

${ }^{55}$ Extraído de SILVA, Fernando Laércio Alves da; VERZELLONI Luca. A mediação penal em Portugal doze anos depois: início, meio e fim(?). Revista de Informação Legislativa. Brasília, n. 227, jul-ago. 2020. No prelo). 